\title{
Perspective of Integrated Management of Bengkulu Coastal Areas Based on Space, Social and Economic Utilization
}

\author{
Edwin Permana ${ }^{1}$, Kamaludin $^{2}$, Yefriza $^{3}$ \\ Faculty of Economics, Universitas Bengkulu, Bengkulu, Indonesia \\ $\left\{\right.$ yefriza147@gmail.com $\left.{ }^{3}\right\}$
}

\begin{abstract}
This research is a quantitative descriptive research with explorative study type. The study was carried out in the Regency Strategic Areas namely South Bengkulu Regency, Kaur Regency and Seluma Regency. 295 respondents consisted of village officials, cooperatives, business groups, fisheries counselors, fishermen, sub-district heads, fisheries offices, DPRD and Bappeda. The main data collection is by distributing questionnaires and supporting data in the form of documents originating from Bappeda and the Central Statistics Agency (BPS) of South Bengkulu Regency, Kaur and Seluma as well as other sources that support research. Data analysis uses multi dimensional scaling (MDS) with rapfish approach to evaluate the sustainability status of integrated coastal area management, and partial least square (PLS) approach, which is a component or variant based structural equation modeling (SEM) model. The results of the study note that the sustainability status of integrated coastal management based on spatial, social and economic use in the Seluma Regency, South Bengkulu and Kaur Districts has a good sustainability status. Sensitive attributes that support from the social aspects ranging from the highest fishing skills, training, community awareness of coastal resources that will be depleted, involvement in the protection of coastal resources to the lowest sensitive attributes involved in institutions. The significant spatial, social and economic use of integrated coastal management in the Seluma, South Bengkulu and Kaur districts, all aspects significantly affect the integrated management of coastal areas.
\end{abstract}

Keywords: Spatial Use; Social; Economic; Integrated Coastal Management

\section{Introduction}

It is almost a practice that any discussion of coastal area management begins with reference to the "interface between land and sea" or the area where land and sea levels meet and interact (Scura, et al., 1992; Lakshmi \& Rajagopalan, 2000). This area is important because it is a link between activities on land and activities in the oceans. Another most important fact about this area is that nature has filled it with all the resources humans need to survive.

Sorensen and McCreary (1990) in their book entitled "Institutional Arrangement for Managing Coastal Resources and Environments", defines coastal areas as borders or spaces 
where two main environments change, namely sea and land. Furthermore, in fact, there are also several definitions of coastal areas used by several marine countries in the world. For example, the State of Indonesia refers to Article 1 of Law Number 1 of 2014 concerning Management of Coastal Areas and Small Islands, defines coastal areas as transitional areas between terrestrial and marine ecosystems that are affected by changes in land and sea.

The combination of freshwater and saltwater in coastal estuaries creates some of the most productive and richest habitats on earth (Cicin-Sain, et al., 1998). These areas are rich in fishing grounds, in the sense that they provide protein, nutrition and food for humans, and play an important role in the economic activity of a nation. According to the Food and Agriculture Organization (FAO), aquaculture carried out in coastal areas has become an important food production sector and greatly contributes to community livelihoods, food security, poverty alleviation, income generation, employment and trade (FAO, 2000).

Currently, coastal areas are increasingly threatened by human activities, especially in developing countries. There are many factors gradually affecting this precious resource. Statistics show that about $60 \%$ of the world's total population lives near coastal areas and two thirds of the world's largest cities are located on the coast (Vandermeulen, 1999; Lakshmi \& Rajagopalan, 2000). In developing countries these two facts have serious adverse effects on the coastal environment, human health and the economies of these countries. Coastal areas are affected by pollution generated by human activities, and industrial operations such as oil exploration, marine disposal, and mineral mining, and over-exploitation of fish (Clark, 1998). The presence of waste near coastal areas; industrial waste, use of pesticides and chemicals on agricultural land and crops, all of these factors contribute to contamination of estuary, bay and coastal waters. The shipping industry as a source of pollution that creates fuel and oil as well as the release of other pollutants and the fact that pollution carried by ships can contain harmful pathogens and aquatic organisms. When dumped into new ecosystems, they can cause adverse effects on marine species, human health and national economies (Lazaroff, 2000).

In 1982, the United Nations Convention on the Law of the Sea caught the attention of the international community. The law of the sea conventions define the rights and responsibilities of states to the use of the world's oceans, setting guidelines for business, the environment, and the management of marine natural resources. Furthermore, Chapter 17 Agenda 21 of the United Nations Conference on Environment and Development (UNCED) held in Rio in 1992 called for the need for integrated management and sustainable development of coastal and marine areas, including the exclusive economic zone. This emphasizes the need for proper management of coastal resources under national control. It also highlights the need for economic development that can meet the needs of present and future generations. In 1993, the World Coast Conference declared that Integrated Coastal Zone Management (ICZM) was the most appropriate process to anticipate and respond to long-term concerns and needs while facing the challenges and opportunities of today. There is an urgent need for coastal states to strengthen their capacity to develop appropriate strategies and programs for integrated coastal management. The Conference Report suggested that integrated coastal zone management should involve a comprehensive assessment, from goal setting, planning, management taking into account traditional, cultural and historical perspectives and the interests of the community. It is a continuous and evolutionary process to achieve sustainable development (World-Coast-Conference- (WCC), 1993).

Noor (2001) in his research in Bangladesh, identified the variables of integrated coastal area management, historical and ecological developments, conflicts and economic activities of shrimp ponds. Noor's research results found that the shrimp farming industry in Bangladesh is an important export-oriented economic activity that has negative ecological impacts on coastal 
zone resources and has positive and negative socio-economic impacts on coastal communities. Noor recommended the establishment of an Integrated Coastal and Marine Management Commission, as well as an evaluation of the environmental impact and strategic zoning of coastal and other resource use areas.

Barker (1991) says that governments in developing countries have started to recognize the importance of coastal zone issues, but the unwillingness or inability to manage coastal resources and protect environmental quality has prevented effective coastal management in most cases. In line with Schernewski (2016) who also adopted Integrated Coastal Zone Management (ICZM) in a sustainable development strategy, namely integrated economic growth, social welfare and environmental protection, and the needs of the current generation are met without sacrificing the ability of future generations to meet their own needs. The Council of Europe recommends integrated coastal zone management (ICZM) by integrating local, regional national, global measures and review of development management.

Hopkins, et al. (2012) developed a framework for a systemic transition approach to sustainable development of coastal areas based on 18 research sites in Europe. Hopkins identifies the sustainable development of coastal areas in Europe through ecological, economic and social variables. The knowledge gained from this experiment concerns the practical aspects of (a) governance in terms of policy effectiveness, (b) sustainable science in the application of transdisciplinary science to socio-ecological problems, and (c) simulation analysis in terms of quantification dysfunctions in systems complex. Further, this research argues that the transition to sustainable development for coastal systems requires consideration of the scale of interdependence from individuals to globally and the possibility of recognizing the emergence of global scale networks that can work together to maximize integrated sustainability between them.

Irime, et al. (2014) states that coastal and marine issues must be addressed through transverse initiatives, namely from the whole and covering all visions of the problem, according to the cause, and not just temporary symptoms. Hoagland, et al. (2012) stated that decisions on coastal area development should be based on economic analysis, but they must also pay attention to issues of justice for existing users and the possible value of resources for future generations, further consideration should be given to the impact of habitat degradation of coastal area resources. According to Laynurak (2008), the management of coastal areas in an integrated manner includes the use and control of coastal resources. Utilization of coastal resources includes living and non-living natural resources, coastal environmental services, built or artificial resources, in terms of control of coastal area resources, must be carried out based on applicable laws and regulations, customary and customary community rights, water management rights, based on local customs and customary laws.

The development problem in Bengkulu Province is also inseparable from its geographical location which is directly adjacent to the Indian Ocean. As one of the coastal areas in Indonesia, the issue of developing coastal areas is increasingly crucial and needs serious attention from the government. Socio-economic development in coastal areas tends to be neglected. Data from the Ministry of Public Works and Public Housing in 2017 shows that several districts in Bengkulu Province are below the provincial poverty average: 


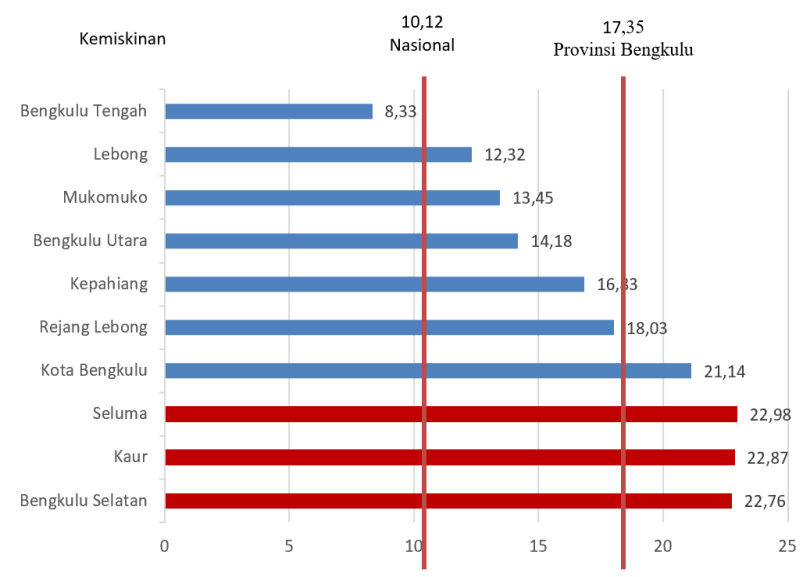

Fig. 1. Comparison of Poverty Levels in Bengkulu Province in 2017 Source: Ministry of Public Works and Public Housing, 2017

Figure 1 shows that the highest poverty rates in Bengkulu Province are in Seluma, South Bengkulu and Kaur districts above the provincial average (17.35) and the national average (20). As Rustiadi, et al. (2009) stated that the development of the superior potential of coastal areas which is carried out in an integrated and sustainable manner in accordance with the regional development plan is expected to increase economic productivity in coastal areas. The ability to spur the growth of a region or region is highly dependent on the superiority or competitiveness of the economic sectors in the region.

The measurement of development success can also be seen from the human development index (HDI). An area with a good HDI level is indicated by the degree of health which is marked by long life, high level of knowledge and a decent life. Data from the Ministry of Public Works and Public Housing in 2017 shows that almost the HDI of districts in Bengkulu Province is below the provincial average (Figure 2). This may indicate that there is still a low level of accountability towards development goals itself, particularly in relation to the human development index.

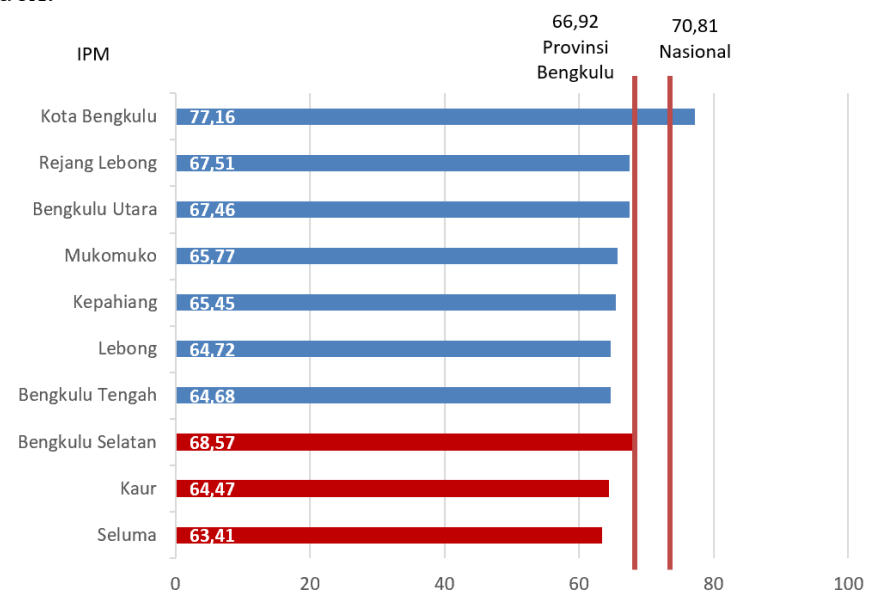

Fig. 2. Comparison of Human Development Index Source: Ministry of Public Works and Public Housing, 2017 
Figure 2 shows that six districts have an HDI below the provincial average. The HDI of Kaur and Seluma Districts is below the Provincial index of 66.92. Although the HDI of South Bengkulu Regency is above the provincial average, it needs attention because it has not yet reached the national index of 70.81. Many factors cause the low HDI in an area, including the low level of economic growth which only relies on the consumption sector, low purchasing power of the people and so on.

The achievement of high economic growth that is achieved by regencies / cities in Bengkulu Province does not necessarily guarantee the creation of equal income between individuals and regions. In fact, economic growth is often followed by inequality in development. Based on data from the Regional Infrastructure Development Agency for the Ministry of Public Works and Public Housing in 2017, Seluma Regency, South Bengkulu Regency and Kaur Regency are included in the underdeveloped index in developing villages.

The coastal areas of Seluma, South Bengkulu and Kaur regencies currently do not have a comprehensive study of coastal area management policies related to management, action, utilization and others. The regional government has not prioritized development in coastal areas (underdeveloped), because it is considered that it does not generate local revenue directly. This area also frequently rises in sea level as a result of the phenomenon of global warming which has a serious impact on coastal areas. The people in this area have a low level of education and are included in areas with poverty levels below the average of Bengkulu Province. The institutional system and management of integrated area development in coastal areas are not yet organized, the infrastructure to support fisheries businesses is inadequate and the management of village data is weak.

\section{Literature Review}

\subsection{Sustainable Development Theory}

Sustainable development is a development process based on the principle of "meeting the needs of the present without sacrificing the needs of future generations". One of the factors that must be faced to achieve sustainable development is how to repair environmental damage without sacrificing the needs of economic development and social justice (Salim, 2000). According to Azapagiz and Perdan (2000) sustainable development aims to improve people's welfare, to meet human needs and aspirations. In essence, sustainable development is aimed at seeking equitable development between present and future generations.

Budimanta, et al. (2008) stated that sustainable development is a way of looking at activities carried out in a systematic and planned manner in the framework of improving the welfare, quality of life and environment of mankind without reducing access and opportunities for future generations to enjoy and use them. In the process of sustainable development there is a process of planned change, in which there is exploitation of resources, the direction of investment in technology development orientation, and institutional changes, all of which are in harmony, as well as increasing the present and future potential to meet the needs and aspirations of the community.

Sustainable development or sustainable development may be realized through the right interlinkages between nature, socio-economic aspects, and culture. They realize that there are limits to the use of natural resources and limits on the ability of the biosphere to absorb human activities, although through mastery of technology these boundaries can become relative. Therefore, sustainable development is not a harmonious situation that is permanent and static, 
but is a process of change in which the exploitation of natural resources, investment direction, technology development orientation, institutional changes are consistent with current and future needs. Likewise, population development needs to be considered in achieving sustainable development, and therefore the number and development of the population must be in balance with changes in the potential for ecosystem products (Djayadiningrat, 2001).

\subsection{Coastal Resources}

Coastal resources are a major source of great value for commercial, recreational and aesthetic reasons. Coastal resources are not as widely distributed spatially as other natural resources, but can be used by populations that are spread across the continental landmass. Coastal resources are usually defined as natural commodities that are often renewable, which depend on the coast. The value of commodities to society has increased considerably because of their location in the coastal zone (Dirhamsyah, 2006). The value of the word is not limited to its fiscal definition, although in most cases of exploitation of coastal resources this is often the highest priority. In this thesis the spatial, social and economic features are considered as resources.

Coastal resources can be divided into six broad groups. Industrial or agricultural products are considered resources if they achieve substantial production gains from the conditions associated with their coastal location. Also included in the image are what could be called coastal environments, such as mangroves, estuaries and coral reefs. The coastal environment is a natural and man-made physical condition that is specific to the coastal zone (eg estuaries) or whose characteristics are determined significantly by its coastal location (eg fishing villages) (Prestelo \& Vianna, 2016). The quality and condition of the coastal environment is directly related to the potential use of resources.

\subsection{Environmental Modernism}

Until the 1960 s, the term environmentalism was a philosophical and scientific term where human actions were determined by the natural environment or their habitat. This idea has a long history in European philosophy. Both Plato and Aristotle argued that human behavior could be explained by climate, and this idea was accepted and developed by many philosophers after them. For example, Montesquieu (1689-1755) argued that the progress of society was mainly stimulated in areas with strong winds and great storms. By the end of 1924, it was claimed that the highest form of religion was found in temperate regions.

After the 1960s, the term environmentalism took on a new meaning. Mainly to refer to the collective social response to environmental degradation and to seek a better future. This modern modernism followed the emergence of environmental activism and ecological movements in the 1960s when groups like Greenpeace spoke of (their views) worrying about the degradation of the natural environment. Environmentalism in a new sense is "discourse". This is a highly politicized discourse, not least because the benefits and costs of environmental change are unequally distributed geographically and socially.

In this report the meaning of discourse is associated with French philosophers Michel Foucault and Pierre Bourdieu. They argue that talk (whether about ethnic groups, environment, or sexuality) is not only descriptive of something. Talking is a kind of social practice that exacerbates the objects it speaks, instead of just pointing at them (Foucault, 1972). Language is not just "about" the experiences and realities that are lived. Language itself is constructive experience and reality. Bourdieu argues that the categories of perceptions about 
the world and the resulting reality correspond to those that are produced together. The discursive process is then a process in which specific world views and categories create understanding by people who have power and are accepted by others, as exemplified by the process by which ICZM has become a way of talking about the environment and coastal people (Foucault, 1972).

\subsection{Social and Economic}

An area will be inhabited by certain communities due to attractive factors, one of which is the potential available natural resources. On the other hand, the area will be abandoned by its inhabitants if the available natural resource potential is very limited, critical, or hopeless. However, certain community activities cannot be separated from the ability of nature to support their lives. It's just that the use that is carried out also depends on the ability of human resources to manage it.

Coastal areas and small islands usually have the characteristic of not being massively developed. In other words, intervention in economic interests is still relatively small, so that the potential and wealth contained in this area is still very large to be explored and utilized for humanitarian purposes. Some of the potentials contained in general (conditions for each area are different) include the following: coastal and marine resources, freshwater resources, land resources, energy resources, tourism resources, biodiversity resources and cultural resources.

Maritime development policies, so far, tend to be more towards "productivity" policies by maximizing the results of exploitation of marine resources without adequate policies controlling them (Syarif, 1993). The social dimension provides information about the carrying capacity (supply capacity) of the natural systems of the coastal area in supporting all development activities and human life. As said by previous researchers, so that the development of coastal areas can be sustainable, the pattern and rate of development must be managed in such a way that the total demand for natural resources and environmental services does not exceed that supply capacity.

\subsection{Hypothesis}

Hypotheses are presumptions or assumptions that must be tested through data or facts obtained through research and are also a guide for researchers in exploring the desired data (Dantes, 2012). There are two types of hypotheses, namely the null hypothesis and the alternative hypothesis (Cooper \& Schindler, 2010). According to Sekaran (2012), the null hypothesis (Ho) is a proposition that states a definitive and precise relationship between two variables. The null statement is defined as no (significant) effect between the two variables. While the alternative hypothesis (Ha) is the opposite of the null hypothesis (Ho) which reveals that there is an influence between variables. Based on this description, the current research uses the null hypothesis ( $\mathrm{Ho})$ and the alternative hypothesis $(\mathrm{Ha})$.

Ha: Spatial, social and economic use affects the integrated management of coastal areas in the districts of Seluma, South Bengkulu and Kaur.

Ho: Spatial, social and economic use do not affect the integrated management of coastal areas in the districts of Seluma, South Bengkulu and Kaur.

\section{Methodology}


This research was conducted with a quantitative descriptive method. The quantitative descriptive research method is a method that aims to create a picture or description of a situation objectively using numbers, starting from data collection, interpretation of the data and appearance and results (Arikunto, 2016). In this study, it is to express facts with the right interpretation in order to find a picture that can explain systematically about integrated coastal area management. Based on the type, this research is an exploratory study. Kuncoro (2012) states that exploratory studies are needed to gain a deeper understanding of the phenomenon under study and are research that aims to develop new knowledge or conjectures and to provide direction for further research.

The descriptive method uses an exploratory approach, chosen because it is rare to find other studies related to the problems to be studied. The research design is designed to cover the overall data collection methods, analysis methods and describe them based on relevant theories and the results of previous research. Operationalization is one step beyond conceptualization (Rubin \& Babbie, 2010). The operational definition of this research refers to a specific definition taken from an extensive literature review in terms of integrated coastal development, spatial use, economic and social. The operational definition of each research variable is:

a. Spatial utilization is an activity to manage coastal space based on function, direction of use, integrated development of coastal and land areas of various interests among development actors in coastal spatial planning for Seluma, South Bengkulu and Kaur Regencies.

b. Economic aspect is the effective and efficient utilization of economic resources in the coastal areas of Seluma, South Bengkulu and Kaur in meeting community needs in accordance with the economic carrying capacity for sustainability.

c. The social aspect is the enhancement of the role of local communities in the management of coastal areas by increasing the knowledge, skills and awareness of the community to do something to protect the coastal natural resources of Seluma, South Bengkulu and Kaur regencies.

d. Integrated coastal area management is the development and conservation of coastal areas in Seluma, South Bengkulu and Kaur districts starting from the local environment to the regions in a participatory manner, namely by integrating the interests of various sectors and different community groups in the management of coastal resources.

e. Sustainability status is an analytical method to evaluate the sustainability of the management of the coastal areas of Seluma, South Bengkulu and Kaur districts in a multidisciplinary manner (spatial, economic and social use) which is based on ordination techniques (placing things in a measurable order of attributes) with Multi-Dimensional Scaling.

Dantes (2012) proposes two approaches that can be taken into consideration to overcome the problem of sample size adequacy in modeling through SEM. The first approach considers the sample size based on the accuracy of the estimation and the effect of the sample size that researchers have found answers to through the Monte Carlo study. Although the results are conflicting, general agreement can be identified. So, the suitability of the sample size is closely related to the shape of the model to be estimated. Fifty observations / cases / samples according to Tanaka are sufficient to test a single latent variable model which has four visible indicators. This amount is not sufficient when applied to a model that has 20 measuring variables with 4 latent variables. However (Ghozali, 2016) suggests that for hypothesis testing using Component Based SEM or Partial Least Square (PLS) analysis, the recommended minimum sample size ranges from 30 to 100 cases or more, the population in this study are all 
stakeholders related to management. an unknown number of the Semaku coastal area.

This study uses quantitative research methods with analytical tools including Multidimensional Scaling (MDS) and SEM PLS. MDS is used to analyze the sustainability of integrated coastal management based on spatial, social and spatial use in Seluma, South Bengkulu and Kaur Regencies, while SEM PLS is to determine the significance of spatial, economic and social use towards integrated coastal management in Seluma Regency, Bengkulu. South and provide recommendations for sustainable management models for the coastal areas of Seluma, South Bengkulu and Kaur districts.

\section{Result and Discussion}

Outer model that defines how each indicator relates to its latent variable. The measurement model (outer model) is used to test construct validity and instrument reliability, namely convergent validity, discriminant validity, average variance extracted (AVE), composite reliability and Cronbach's alpha. Convergent validity of the measurement model with reflective indicators can be seen from the correlation between item / indicator scores and construction scores. Hair et al. (2010) suggest that the rule of thumb which is usually used to make initial checks of the factor matrix \pm 0.30 to \pm 0.40 is considered to have met the minimum level for conveying constructs, the loading value of \pm 0.50 is considered practical, and the loading value is \pm 0 . , 70 indicates a better loading value in presenting the construct. According to Abdillah \& Hartono (2015), the higher the loading factor value, the more important the role of loading is in interpreting the factor matrix. Table 18 below shows the results of the calculation of outer loading for all the indicators that make up the construct / research variable, where the correlation value is above 0.70 which means that the indicators of a construct have good validity.

Table 1. Outer Model

\begin{tabular}{ccccc}
\hline Indicators & $\begin{array}{c}\text { Economic } \\
\text { Aspects (ae) }\end{array}$ & $\begin{array}{c}\text { Social } \\
\text { Aspects (as) }\end{array}$ & $\begin{array}{c}\text { Spatial } \\
\text { planning (pr) }\end{array}$ & $\begin{array}{c}\text { Coastal Zone } \\
\text { Management (pwp) }\end{array}$ \\
\hline ae2 & 0,585881 & 0,513946 & 0,508711 & 0,526242 \\
ae3 & 0,725056 & 0,461570 & 0,654207 & 0,552725 \\
ae4 & 0,729682 & 0,418432 & 0,517877 & 0,395078 \\
ae5 & 0,691817 & 0,471940 & 0,521253 & 0,382298 \\
ae6 & 0,571484 & 0,348632 & 0,415450 & 0,361282 \\
ae7 & 0,641220 & 0,368336 & 0,339705 & 0,336266 \\
ae8 & 0,655785 & 0,370423 & 0,365402 & 0,404767 \\
ae9 & 0,712429 & 0,517507 & 0,435896 & 0,472044 \\
as1 & 0,624166 & 0,730063 & 0,371944 & 0,324794 \\
as10 & 0,409631 & 0,649413 & 0,316438 & 0,438701 \\
as2 & 0,171163 & 0,675188 & 0,204116 & 0,044217 \\
as3 & 0,214567 & 0,741303 & 0,197509 & 0,329909 \\
as4 & 0,457251 & 0,663114 & 0,431156 & 0,441054 \\
as5 & 0,432463 & 0,536304 & 0,333563 & 0,282263 \\
as6 & 0,451919 & 0,759712 & 0,443703 & 0,488816 \\
as7 & 0,524060 & 0,812247 & 0,460352 & 0,591647 \\
as8 & 0,530074 & 0,801080 & 0,513164 & 0,644092 \\
as9 & 0,515824 & 0,625084 & 0,525666 & 0,486117 \\
pr1 & 0,520406 & 0,422362 & 0,753422 & 0,609990 \\
pr10 & 0,337978 & 0,310175 & 0,671948 & 0,219182
\end{tabular}




\begin{tabular}{ccccc}
\hline Indicators & $\begin{array}{c}\text { Economic } \\
\text { Aspects (ae) }\end{array}$ & $\begin{array}{c}\text { Social } \\
\text { Aspects (as) }\end{array}$ & $\begin{array}{c}\text { Spatial } \\
\text { planning (pr) }\end{array}$ & $\begin{array}{c}\text { Coastal Zone } \\
\text { Management (pwp) }\end{array}$ \\
\hline pr2 & 0,470271 & 0,433289 & 0,715450 & 0,524120 \\
pr3 & 0,466201 & 0,355392 & 0,694644 & 0,358578 \\
pr4 & 0,400299 & 0,302111 & 0,698319 & 0,387626 \\
pr5 & 0,606499 & 0,332934 & 0,762488 & 0,591559 \\
pr6 & 0,491006 & 0,337289 & 0,755442 & 0,513047 \\
pr7 & 0,530231 & 0,400712 & 0,693404 & 0,466246 \\
pr8 & 0,488018 & 0,619224 & 0,608694 & 0,493053 \\
pr9 & 0,495172 & 0,625213 & 0,796909 & 0,540875 \\
pwp1 & 0,472134 & 0,598545 & 0,512968 & 0,783279 \\
pwp10 & 0,549994 & 0,544697 & 0,537331 & 0,802438 \\
pwp2 & 0,479268 & 0,533889 & 0,591400 & 0,796491 \\
pwp3 & 0,444085 & 0,553147 & 0,585824 & 0,716930 \\
pwp4 & 0,497449 & 0,489710 & 0,575787 & 0,685780 \\
pwp5 & 0,204973 & 0,176514 & 0,627179 & 0,681924 \\
pwp6 & 0,501034 & 0,548224 & 0,556880 & 0,772473 \\
pwp7 & 0,521225 & 0,588317 & 0,605366 & 0,735430 \\
pwp8 & 0,449642 & 0,416016 & 0,464363 & 0,668317 \\
pwp9 & 0,577077 & 0,507617 & 0,584831 & 0,759861 \\
\hline & & Sumber: Data processing 2019 &
\end{tabular}

The statistical test of each hypothesized relationship in the PLS was carried out by using a simulation, namely comparing the t-statistic value with the t-table (1.650). In this case, the bootstrap method is carried out on the data as shown in Figure 16.Testing with the bootstrap is also intended to minimize the problem of abnormal research data.

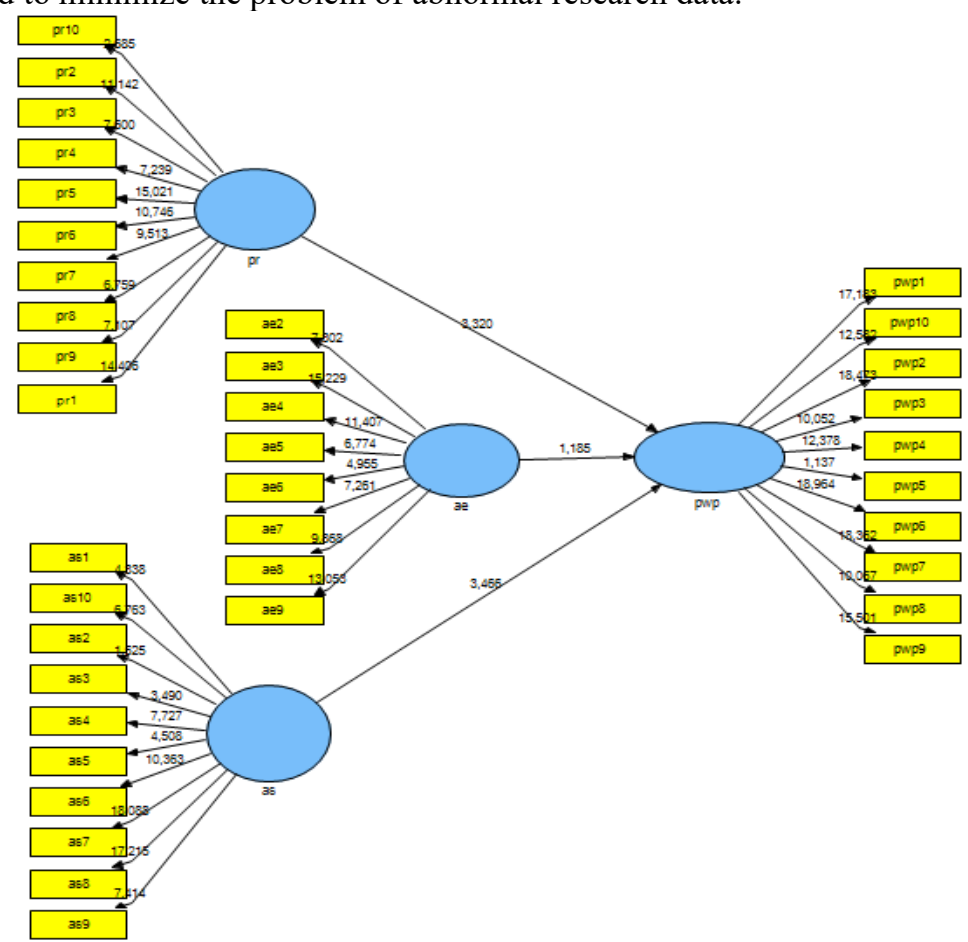

Fig. 3. PLS Bootstrapping Results 
Figure 3 is the result of bootstrapping which is intended to minimize the problem of abnormal research data, this figure shows that the indicators have high statistical values for the variables. For a more complete significance of the model in hypothesis testing, it can be seen from the t-statistic value in the total effects table (direct effect) table 2.

Table 2. Total Effects (Mean, STDEV, T-Values)

\begin{tabular}{lccccc}
\hline & $\begin{array}{c}\text { Original } \\
\text { Sample (O) }\end{array}$ & $\begin{array}{c}\text { Sample } \\
\text { Mean (M) }\end{array}$ & $\begin{array}{c}\text { Standard } \\
\text { Deviation } \\
\text { (STDEV) }\end{array}$ & $\begin{array}{c}\text { Standard Error } \\
\text { (STERR) }\end{array}$ & $\begin{array}{c}\text { T Statistics } \\
(\mid \mathbf{O} / \text { STERR|) }\end{array}$ \\
\hline pr -> pwp & 0,408815 & 0,399196 & 0,107837 & 0,107837 & $3,791031^{*}$ \\
as -> pwp & 0,369599 & 0,384720 & 0,097278 & 0,097278 & $3,799395^{*}$ \\
ae ->pwp & 0,312123 & 0,324223 & 0,098456 & 0,098456 & $3,325487^{*}$ \\
\hline
\end{tabular}

The third hypothesis testing in table 2 shows that space utilization is significant for the integrated coastal area management, where the t-statistic is calculated $(3,791)>t$-table $(1,650)$. Thus it can be concluded that the hypothesis which states significant spatial use of integrated coastal area management can be accepted (Ha accepted). This means that the better the spatial use of an area, the more integrated the management of the coastal area is, on the other hand, the lower the spatial use of an area, the less integrated the management of the coastal area will be.

The second hypothesis testing in table 2 shows that the social aspect is significant for the integrated coastal area management, where the t-statistic is calculated $(3,799)>t$-table $(1,650)$. Thus it can be concluded that the hypothesis which states that the social aspects are significant to integrated coastal area management can be accepted (Ha accepted). This means that the better the social aspects of an area, the more integrated the coastal area management will be, conversely the lower the social aspects of an area, the less integrated the coastal area management will be.

Table 2 shows that the economic aspect (ae) is significant for the integrated coastal area management where the t-statistic is calculated $(3,325)>$ t-table $(1,650)$. Thus it can be concluded that the hypothesis which states that the economic aspects are significant to the integrated coastal area management is accepted (Ha accepted). This means that the better the economic aspect of an area, the more integrated the management of the coastal area will be, conversely the lower the economic aspect of an area, the less integrated the management of the coastal area will be.

Based on the results of research and discussion conducted in the previous sub-chapter that spatial use, social and economic aspects have a significant effect on integrated coastal management, this research has implications for the policies of the Seluma, South Bengkulu and Kaur regencies. Local governments must make clear instruments that serve as directions or arrangements in managing and investing in development activities in coastal areas.

The Kaur Regency Government needs to carry out routine dredging of the landing channel for boat moorings in Kaur Regency, especially in the Linau and Old Market areas. Local governments can build and improve fishing ports in order to advance the marine sector for capture fishermen. Establishment of a mooring location is very important, especially during bad weather conditions. This is because the beach in Kaur Regency which faces the Indian Ocean during the West monsoon has the potential for high waves and can damage boats. Meanwhile, for non-sea binding activities, the local government can encourage fishermen to cultivate catfish with tarpaulin in front of fishermen's houses. In addition, the local government must immediately resolve the problem of land acquisition for shrimp fishermen, because this non-marine fishery activity is quite potential in Kaur Regency. 
The Regional Government of South Bengkulu Regency must intervene in the arrangement for fishermen settlements in Pasar Bawah, so as not to interfere with each other's tourism development. There needs to be a relocation of fishermen settlements that are on the same side of the coast and this location can be used for marine tourism development activities. From the results of intensive field observations it is known that there is a consumptive pattern of fishermen in South Bengkulu Regency. After harvesting, fishermen spend a lot of their harvest in Bengkulu City, so that one week they do not go to sea. Thus, it is necessary to socialize the local government to reduce the consumptive behavior of fishermen in South Bengkulu Regency. Then there needs to be support from the Regional Government of South Bengkulu Regency for the cultivation of marine fisheries through pontoon and providing boat assistance with a capacity of more than $5 \mathrm{gt}$, because currently fishing boats only have a maximum capacity of $5 \mathrm{gt}$ so that cruising is limited and the catch is inadequate.

For Seluma Regency, the classic problem is the conflict between fishermen of Seluma Market and fishermen who use trawlers from Bai Island. Even though the efforts of the Regional Government have been made, these efforts are still considered not optimal because they are still incidental, where the government only intervenes if the conflict has taken the form of a physical collision.

According to the author, the Regional Government's policy regarding the prohibition of fishing gear must of course be followed by alternative replacement solutions tailored to the needs of fishing communities and local socio-economic conditions and geography, so that policies do not continue to reap pros and cons and do not cause new conflicts in the community. There is a clear mapping of fishing areas according to the type of vessel and fishing gear as well as their sizes, as well as strict supervision in order to discipline and implement policies taken, take firm action against violators and pay attention to all aspects that will have an impact for fishermen.

\section{Conclusion}

Based on the results of research and data analysis that has been carried out in the previous chapter, the following conclusions can be drawn, that the status of the sustainability of integrated coastal area management as a whole is good. Sustainable use of space has a good sustainability status. With this index, basically the spatial use of the coastal areas of Seluma, South Bengkulu and Kaur Regencies can be relied on as the carrying capacity of integrated coastal management. Sensitive attributes that affect the sustainability of spatial use start from the highest base of permits, integration of the substance of the spatial plan, synergy between interests and sequentially to the smallest sensitive attributes other uses are not suitable for the function of the area. Sustainability of economic aspects with good sustainability. This condition explains that basically the social aspects of the coastal communities in the districts of Seluma, South Bengkulu and Kaur can be relied on as the carrying capacity of integrated coastal area management. Sensitive attributes that leverage economic aspects range from the highest level of community economic empowerment, fishing technology, non-fishery activities, development of small businesses and cooperatives and so on to the lowest sensitive attributes of microfinance institutions. The sustainability of social aspects with good sustainability status. Sensitive attributes that support social aspects ranging from the highest fishing skills, training, community awareness of coastal resources that will be depleted, involvement in the protection of coastal resources to the lowest sensitive attributes of incorporation in institutions. 
Of the three aspects tested (spatial, social and economic use) that are significant for integrated coastal management in the Seluma, South Bengkulu and Kaur districts, all significant aspects affect the integrated management of coastal areas. Economic aspects are significant for integrated coastal area management. This means that the better the economic aspect of an area, the more integrated the management of the coastal area will be, conversely the lower the economic aspect of an area, the less integrated the management of the coastal area will be. Significant social aspects of integrated coastal area management. This means that the better the social aspects of an area, the more integrated the coastal area management will be, conversely the lower the social aspects of an area, the less integrated the coastal area management will be. Utilization of significant space for integrated coastal area management. This means that the better the spatial use of an area, the more integrated the management of the coastal area will be, conversely the lower the spatial use of an area, the less integrated the management of the coastal area will be.

\section{References}

[1] Abdillah, W. \& Hartono, 2015. Partial Least Square (PLS). Yogyakarta: Andi.

[2] Arikunto, S., 2016. Prosedur Penelitian Suatu Pendekatan Praktik. Jakarta: Rineka Cipta.

[3] Azapagiz, A. \& Perdan, S., 2000. Indicators of Sustainable Development for Industry, A General Framework. USA: University of Surrey.

[4] Barker, T. D. G., 1991. A plan for coastal zone integrated resource management in a developing south west pacific island country. Canada, University of New Brunswick.

[5] Budimanta, A., Prasetijo, A. \& Rudito, B., 2008. Corporate social responsibility, alternatif bagi pembangunan indonesia. Jakarta: Indonesia Center for Sustainable Development.

[6] Cicin-Sain, Robert, B. \& Knecht, W., 1998. Integrated Coastaland Ocean. Management. Washington DC: The Islands Press.

[7] Clark, J. R., 1998. Coastal seas: the conservation challenge. Cornwall, UK: Blackwell Science Ltd.

[8] Cooper, D. R. \& Schindler, P. S., 2010. Business Research Methods. New York: MacGraw-Hill/Irwin.

[9] Dantes, N., 2012. Metode Penelitian. Yogyakarta: Andi.

[10] Dirhamsyah, 2006. Pengelolaan wilayah pesisir terintegrasi di Indonesia. Ocean and Coastal Management Journal, 31(1), pp. 21-26.

[11] Djayadiningrat, 2001. Untuk Generasi Masa Depan - Pemikiran, Tantangan dan Permasalahan Lingkungan. Bandung: ITB Press.

[12] FAO, 2000. Year Book of Fishery Statistics-Catche Sand Landing. FAO Fish. Ser, Volume 54, pp. 209-210.

[13] Foucault, M., 1972. The Archaeology of Knowledge and The Discourse on Language. New York: Pantheon Books.

[14] Ghozali, I., 2016. Aplikasi Analisis Multivariate Dengan Program SPSS. 2nd penyunt. Semarang: Badan Penerbit Universitas Diponegoro.

[15] Hair, J. F., Celsi, M., Ortinau, D. J., \& Bush, R. P. (2010). Essentials of marketing research (Vol. 2). New York, NY: McGraw-Hill/Irwin. 
[16] Hoagland, P., Kite-Powell, H. L., Jin, D. \& Solow, A. R., 2012. SupplysideApproachesto The Economic Valuaion of Coastal and Marine Habitat in The Red Sea. Journal of King Saud University-Science, 25(6), pp. 217-228.

[17] Hopkins, T. S. et al., 2012. A Systems Approach Framework for the Transition to Sustainable Development: Potential Value Based on Coastal Experiments. Ecology and Society, 17(3), pp. 39-50.

[18] Irime, S., Gal, J. \& Dumitrescu, C. D., 2014. Analysis of a Dynamic Regional System for the Operationalizing of the Suitainable Development Concept. Procedia Social and Behavioral Science, 124(2), pp. 331-338.

[19] Kuncoro, M., 2016. Metode Kuantitatif. Yogyakarta: YKPN.

[20] Lakshmi, A. \& Rajagopalan, R., 2000. Socio-economic Implications of Coastal Zone. Degradation and their Mitigation: a Case Study from Coastal Villages in India. Ocean \& Coastal Management, Volume 43, pp. 749-762.

[21] Lazaroff, C., 2000. Ballast Water Brings Diseases From Far Off Ports. [Online] Available at: http://ens.lycos.com/ ens/nov2000/2000L-11-02-15.html [Diakses 2 Juny 2018].

[22] Laynurak, Y. M., 2008. Model Diversifikasi Usaha Masyarakat Pesisir dan Implikasinya Terhadap Kesejahteraan Serta Kelestarian Sumber Daya Wilayah Pesisir Di Kabupaten Belu- NTT. Semarang, FPIK Universitas Diponegoro.

[23] Noor, A. Y., 2001. An evaluation of integrated coastal and ocean management as a means for sustainable development : a case study : the environmental and socioeconomic impact of shrimp farming in Bangladesh. Bangladesh, World Maritime University.

[24] Prestelo, L. \& Vianna, E. M., 2016. Identifying multiple-use conflicts prior to marine spatial planning: A case study of A multi-legislative estuary in Brazil. Elsevier. Marine Policy, 67(20), pp. 83-93.

[25] Rubin, A. \& Babbie, E., 2010. Research Methods for Social Work, Seventh Edition. USA: Cengage Learning.

[26] Rustiadi, E., Saefulhakim, S. \& Panuju, 2009. Perencanaan dan Pengembangan Wilayah. Jakarta: Crespent Press dan Yayasan Obor Indonesia.

[27] Salim, E., 2000. Kembali ke Jalan Lurus : Pengembangan Bangunan Tinggi Berwawasan Lingkungan. Jakarta: Alvabet.

[28] Schernewski, G., 2016. EUCC'smagazine 'Coastal \& Marine' Special 'Recalling ICZM. Insights from the Baltic, 25(2), pp. 78-81.

[29] Scura, L. F., Chua, T. E., Pido, M. D. \& Paw, J. N., 1992. Lessons for integrated coastal zone management: the ASEAN experience. Integrative Framework and Methods for Area Management, 37(2), pp. 1-70.

[30] Sekaran, U., 2012. Research Methods for Business. Jakarta: Salemba Empat.

[31] Sorensen, J. C. \& McCreary, S. T., 1990. Institutional Arrangements for Managing Coastal Resources and Environments. USA: National Park Service.

[32] Syarif, 1993. Pemberdayaan Ekonomi Rakyat. Jakarta: Pustaka Quantum.

[33] Vandermeulen, J. H., 1999. Urbanization of the global coastal zone: implications for human health and living and non-living resources. Chicago and London: The University of Chicago Press.

[34] World-Coast-Conference-(WCC), 1993. Noordwijk Guidelines for Integrated Coastal Zone Management. Noordwijk: Ministry of Transport. Public Works and Water Management National Institute for Coastal and Ocean Management Centre, 13-(2), pp. $1-20$ 
